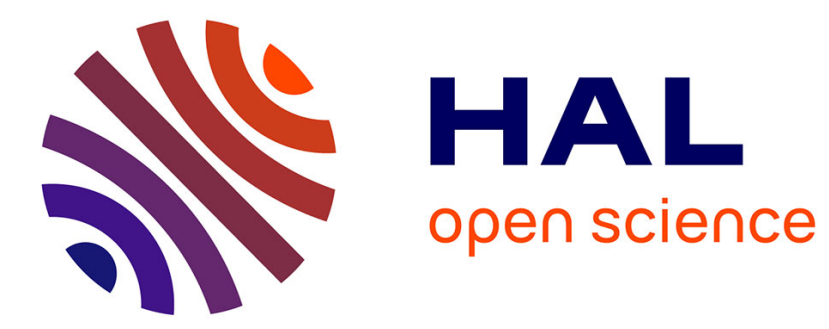

\title{
Impacts of seawater desalination on the giant Australian cuttlefish in the upper Spencer Gulf, South Australia
}

\author{
Jacqueline L Dupavillon, Bronwyn M Gillanders
}

\section{To cite this version:}

Jacqueline L Dupavillon, Bronwyn M Gillanders. Impacts of seawater desalination on the giant Australian cuttlefish in the upper Spencer Gulf, South Australia. Marine Environmental Research, 2009, 67 (4-5), pp.207. 10.1016/j.marenvres.2009.02.002 . hal-00563071

\section{HAL Id: hal-00563071 \\ https://hal.science/hal-00563071}

Submitted on 4 Feb 2011

HAL is a multi-disciplinary open access archive for the deposit and dissemination of scientific research documents, whether they are published or not. The documents may come from teaching and research institutions in France or abroad, or from public or private research centers.
L'archive ouverte pluridisciplinaire HAL, est destinée au dépôt et à la diffusion de documents scientifiques de niveau recherche, publiés ou non, émanant des établissements d'enseignement et de recherche français ou étrangers, des laboratoires publics ou privés. 


\section{Accepted Manuscript}

Impacts of seawater desalination on the giant Australian cuttlefish Sepia apama in the upper Spencer Gulf, South Australia

Jacqueline L Dupavillon, Bronwyn M Gillanders

PII:

S0141-1136(09)00025-7

DOI:

10.1016/j.marenvres.2009.02.002

Reference:

MERE 3318

To appear in:

Marine Environmental Research

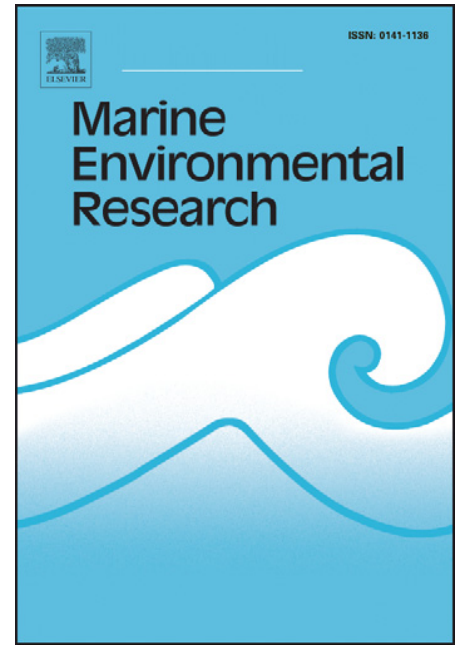

Received Date: $\quad 5$ November 2008

Revised Date: $\quad 11$ February 2009

Accepted Date: $\quad 21$ February 2009

Please cite this article as: Dupavillon, J.L., Gillanders, B.M., Impacts of seawater desalination on the giant Australian cuttlefish Sepia apama in the upper Spencer Gulf, South Australia, Marine Environmental Research (2009), doi: 10.1016/j.marenvres.2009.02.002

This is a PDF file of an unedited manuscript that has been accepted for publication. As a service to our customers we are providing this early version of the manuscript. The manuscript will undergo copyediting, typesetting, and review of the resulting proof before it is published in its final form. Please note that during the production process errors may be discovered which could affect the content, and all legal disclaimers that apply to the journal pertain. 
12 Southern Seas Ecology Laboratories, DX 650 418, School of Earth and Environmental

$17 *$ Corresponding author.

$18 P h \quad:+6188303$ 6235, Fax : +61883034364.

19 E-mail address: bronwyn.gillanders@adelaide.edu.au 


\section{Abstract}

With seawater desalination expanding rapidly, it is important that ecological studies are undertaken to determine the effects of brine discharge on the marine species

24 in the area. The abundance of giant Australian cuttlefish (Sepia apama, Gray 1849) eggs and environmental data were recorded at nine sites near Point Lowly, Spencer Gulf, South Australia, an area where the largest desalination plant in the Southern hemisphere is proposed. In addition, the effects of different concentrations of desalination brine on the growth, survival and condition of cuttlefish embryos were investigated. The primary egg-laying sites for the cuttlefish were in the vicinity of Stony Point (sites 4 and 3) and the area with the least egg abundance was on the eastern and western areas around Point Lowly (sites 9 and 7) where no eggs were found. The survival of embryos decreased with an increase in salinity, with no embryos surviving to full term in salinities greater than $50 \%$. Mean weight and mantle length also decreased with increasing salinity. Besides elevated salinity, the brine also had increased concentrations of $\mathrm{Ba}, \mathrm{Ca}, \mathrm{K}, \mathrm{Sr}$ and $\mathrm{Mg}$ relative to water near Point Lowly. Brine discharge from seawater desalination poses a potential threat to the unique spawning aggregation of the giant Australian cuttlefish, in the upper Spencer Gulf, South Australia. 


\section{Introduction}

With only $1 \%$ of freshwater available for agriculture, industrial and domestic purposes, freshwater resources are a precious commodity. Water scarcity is projected to increase across much of the globe with severe water shortages predicted to affect 2.7 billion people in over 80 countries in the next century (Barker et al., 2000). Water, like energy in the late 1970s, is likely to become the most critical natural resource issue to confront our environment and economy. The inherent need for freshwater has hence encouraged the rapid development of desalting technologies (URS, 2002).

Desalination refers to the wide range of technical methods designed to remove salts from waters of different qualities (Gleick et al., 2006). Seawater desalination is a process in which large volumes of feed water are drawn into a desalination plant from the ocean and salts are removed using, most commonly, reverse osmosis. The process as a whole is not without environmental and ecological implications. Impingement and entrainment of marine organisms via the intake pipes is a major environmental concern (York and Foster, 2005; Gleick et al., 2006). The most significant problem associated with seawater desalination however, is the disposal of the highly concentrated brine effluent produced by desalination plants as by-product which is often discharged into the sea (Arnal et al., 2005). Typical desalination brines contain approximately 50\% more salt than the feed water (1.3-1.7 times the amount of salts) (Einav et al., 2002) and have a higher specific density (Gleick et al., 2006). Desalination brine can have salinities as high as $\sim 70 \%$ to $80 \%$, although the operational technical limit is $70 \%$ (Arnal et al., 2005).

The impact of desalination brine on the marine environment takes place mainly at the point source, in the vicinity of the brine discharge pipe. Even though the brine contains natural marine ingredients, without prior mixing, its high specific weight causes it to sink to the sea floor forming a stratified system with the brine forming a bottom layer (Jibril and Ibrahim, 2001; Einav et al., 2002; Fernández-Torquemada et al., 2005). As the plume sinks, its effects potentially could extend over a range of hundreds of meters. Desalination discharge alters the amount of dissolved oxygen in the water if there is insufficient mixing, water temperature is increased due to the heat treatment within the process and turbidity can be increased at the outlet point (Gleick et al., 2006; Raventos et al., 2006). Desalination brine also may contain many contaminants and hazardous wastes (Gleick et al., 2006). These include anti-fouling agents, chlorine and acid which are unavoidably needed in large scale plants to treat the feed water and 
pipelines. These constituents are not usually treated to remove toxicity before being discharged into the sea (Hashim and Hajjaj, 2005). Brine from seawater desalination can also contain high concentrations of elements which are typically found in seawater, including heavy metals such as lead, manganese, copper and zinc.

Although heavy metals and toxic chemicals can be detrimental to marine organisms, salinity is one of the most important physio-chemical factors to which they are exposed (D'Aniello et al., 1989). Marine organisms exist in osmotic balance with their environment and the osmotic stresses acting on different species depend upon individual adaptations and salinity tolerances within specific habitats. The repercussions of high salinity levels on marine ecosystems and organisms can take a variety of forms. Animals which are not adapted to such conditions often move away from the affected area (Young and Potter, 2002). Species richness and density can also decline where extreme salinities are prominent (Bayly, 1972; Vega-Cendejas and Hernández de Santillana, 2004). Increases in the concentration of salts may result in the dehydration of cells, and the inability to hypoosmotically regulate leading to a decrease of turgor pressure and mortality, especially in larvae, eggs and juveniles (Cintron, 1970; Aladin, 1991; Einav et al., 2002; Young and Potter, 2002).

Increases in salinity can produce smaller embryos. For example, a distinct relationship between salinity, egg size and embryonic development was found in the estuarine crab Chasmagnathus granulata (see Giménez and Anger, 2001). The smaller the hatchling, the greater the physical constraints imposed on the functional morphology of organs responsible for swimming and food capture (Boyle and Boletzky, 1996), which in turn, lessens the individuals' chances of survival. Importantly, salinity directly affects embryonic development in cephalopods (D'Aniello et al., 1989; Sen, 2005). Previous research on the effects of salinity within cephalopods has focused on Loligo spp., and few studies have investigated effects of salinity on Sepia spp. What has been found however is that salinity ranges for embryonic development and hatching success are species specific and higher salinities (28\% \% $38 \%$ ) appear to be optimal (Palmegiano and Dapote, 1983; Paulij et al., 1990; Cinti et al., 2004; Sen, 2005). Growth rates of cephalopods are also affected by salinity, where lower salinities increase statolith size (Villanueva et al., 2007), but also cause deformations of embryos (Paulij et al., 1990). At present there is no published information on the effects of high salinities $(>42 \%$ ) especially those typical of desalination brine $(\sim 70 \%$ to $80 \%$ ) on the growth and survival of the cephalopod embryo or juvenile stage. 

embryos to the potential environmental pressures administered from desalination will

111 aid in managing the population to ensure its long term survival. A proposal exists to

112 build the largest seawater desalination plant in the Southern hemisphere at Port

113 Bonython in the upper Spencer Gulf, South Australia. Effluent consisting of highly

114 concentrated brine will be discharged in the vicinity of the breeding ground of

115 S. apama, thereby having the potential to impact the population. S. apama form a

116 unique annual spawning aggregation, not exhibited by any other cuttlefish species in the

117 world, during winter in the upper Spencer Gulf (Hall and Hanlon, 2002; Hall and

118 Fowler, 2003). The Gulf is considered an inverse estuary with high natural salinities

119 ( $40 \%$ \% $-43 \%$ near Point Lowly) (Nunes and Lennon, 1986). The breeding ground for

120 S. apama lies within $\sim$ 2-8 $\mathrm{m}$ of relatively shallow water with large areas of benthic

121 rocky substratum. S. apama require a hard surface upon which their eggs can be laid

122 and the rocky reef areas at Point Lowly through to Black Point provide this unique

123 habitat.

124 The overall objective of this study was to determine the potential impacts of 125 seawater desalination on the egg stage of $S$. apama in the upper Spencer Gulf.

126 Therefore, this project aims to determine: (1) the distribution and abundance of clutches

127 of eggs of S. apama throughout the breeding aggregation, (2) environmental parameters

128 and water quality in the vicinity of Port Bonython, pre-desalination, and (3) the effects

129 of increased salinity on the embryonation period, survival and condition of cuttlefish

130 hatchlings via a laboratory experiment.

131

132

2. Methods

1332.1 Study site and study species

Data collection and field sampling were made at nine sites in the coastal waters

136 between Black Point and Point Lowly in the upper Spencer Gulf (Fig. 1, Table 1). This

137 area is where the dense spawning aggregation of $S$. apama occurs every winter from

138 May to August. The key breeding ground occurs along approximately $8 \mathrm{~km}$ of coastline

139 (with a subtidal reef area of $0.64 \mathrm{~km}^{2}$ ) from Point Lowly west towards Black Point (Fig.

140 1). The coastline consists of a platform of plate-like fragments of dense quartzite

141 bedrock (Gostin et al., 1984), which extends out beyond the intertidal zone and 
142 gradually becomes low relief subtidal rocky reef out to $70-130 \mathrm{~m}$ off shore ( $8 \mathrm{~m}$ depth)

143 (Hall and Fowler, 2003). Vast areas of this rocky substratum provide ideal egg

144 attachment surfaces where females lay clusters of individual lemon-shaped eggs on the 145 underside of sub-tidal crevices, rocks and overhangs (Cronin and Seymour, 2000; Hall

146 and Fowler, 2003). The embryonic development time of 3-5 months varies according to

147 the time at which the egg was laid. Eggs laid in May for example, will develop over

148 four months and hatch in October and eggs laid later in the season, in August,

149 experience warmer water temperatures and hatch in November (Hall and Fowler, 2003).

150 This unique habitat lies within the oceanographic region of Spencer Gulf, South

151 Australia. This particular gulf system is a semi-enclosed body of water, often termed an

152 inverse estuary, approximately $300 \mathrm{~km}$ long with a maximum width of $130 \mathrm{~km}$ and a

153 typical depth of $40 \mathrm{~m}$ at the southern opening (Fig.1a). In the channels of the northern

154 reaches it is around 15-20 m whilst most coastal zones range between 2 and $8 \mathrm{~m}$ depth

155 near Black Point, Point Lowly and south of Whyalla. The area receives little rainfall,

156 has minimal runoff, little input of groundwater and high evaporation. The head of the

157 gulf therefore exhibits hypersaline conditions where salinity can reach $48 \%$ in late

158 summer (Nunes Vas et al., 1990). Oceanic salinity values are found at the entrance to

159 the gulf.

160

161

\subsection{Abundance of clutches}

162

163

Egg abundance was determined during July 2007 and 2008 at each of the 9 sites by underwater visual strip transects undertaken on SCUBA. Underwater visual survey techniques are an effective, non-destructive method for estimating the abundances of marine organisms (Edgar et al., 2004), but may underestimate the abundance of eggs which are generally laid on the underside of rocks and well-hidden. We therefore only present data on number of clutches of eggs, and would expect any bias in counts (e.g. under counting) to be consistent across sites. Six replicate transects of $20 \mathrm{~m}$ length were sampled at each site. Two to three divers counted the number of clutches of eggs while searching to $1 \mathrm{~m}$ either side of the transect line; the area covered per site was $240 \mathrm{~m}^{2}$.

172 Clutches were defined as a group of two or more eggs. 
Water quality was analysed and environmental parameters determined in July and August 2007 during the peak egg developmental period of the giant Australian cuttlefish. Samples for analysis of nutrients and trace elements were taken from the 9 sites within the known breeding ground where numbers of clutches of eggs were estimated (Fig. 1b; Table 1).

Surface water samples for analysis of nutrients and water chemistry were taken (approximately $15 \mathrm{~cm}$ below surface) via $20 \mathrm{ml}$ plastic sterilised syringes ( $n=6)$ at each of the 9 sites. Samples for nutrient analysis $(n=3)$ were then filtered through $0.45 \mu \mathrm{m}$ glass fibre filters into $15 \mathrm{ml}$ sample containers and stored frozen prior to analysis. Nutrient samples were then analysed for concentrations of dissolved ammonia $\left(\mathrm{NH}_{3 / 4}{ }^{+}\right)$, oxidised nitrogen $\left(\mathrm{NO}_{\mathrm{x}}\right)$, and orthophosphate (OP) on a Lachet FIA (Flow Injection Analysis) Automated Ion Analyser.

\subsection{Water chemistry}

Samples for water chemistry ( $n=3$ ) were also filtered through $0.45 \mu \mathrm{m}$ glass fibre filters but placed into acid washed $30 \mathrm{ml}$ sample containers containing $500 \mu \mathrm{L}$ of nitric acid $\left(\mathrm{HNO}_{3}\right)$ [70\%] and refrigerated for trace element analysis. These samples were analysed by the National Measurement Institute (NMI) for trace elements (Calcium (Ca), Magnesium (Mg), Potassium (K), Strontium (Sr), Barium (Ba), Iron (Fe), Zinc (Zn), Manganese (Mn) and Copper (Cu)). A Perkin Elmer 6000 DRC (Dynamic Reaction Cell) Inductively Coupled Plasma-Mass Spectrometer (ICP-MS) was used to detect the concentrations within each sample. High resolution ICP-MS was used to determine $\mathrm{Zn}$ concentrations to remove interference of molecular ions originating from $\mathrm{NaCl}, \mathrm{S}, \mathrm{Mg}, \mathrm{K}$, and $\mathrm{Ca}$. Lutetium and indium were used as internal standards to correct for ICP-MS drift. Cu and Mn were omitted from further analyses because the readings were below detection limits.

\subsection{Environmental parameters}

A YSI 6600 Multi-parameter Water Quality Meter (CTD sonde) was used to obtain data on depth, temperature, salinity, $\mathrm{pH}$ and dissolved oxygen (DO) at each site. The sonde was slowly lowered from the side of a boat and took recordings from the surface to the bottom for 90 seconds with 3-7 second intervals between each reading. 
207 On the first sampling occasion readings were taken for all sites and replicate drops were

208 conducted. On the second sampling occasion only one set of recordings were taken and some sites were not sampled due to rough sea conditions.

210

2.6 Embryo growth experiment

212

\subsubsection{Egg collection}

Sepia apama eggs were collected from Stony Point (site 4; 3259"5'S, 13743"1'E) in the upper Spencer Gulf, South Australia (Fig. 1b), during July 2007.

216 Newly laid eggs that were soft, bright white and opaque in appearance were collected

217 (Hall and Fowler, 2003). Eggs were gently prised off the underside of rocks by hand 218 and placed into mesh catch bags. Eggs $(n=120)$ were then transferred to a plastic bucket underwater to prevent dehydration and transported to the University of Adelaide in an insulated $20 \mathrm{~L}$ foam box whilst being aerated.

\subsubsection{Experimental set up}

Eggs were maintained in a controlled temperature room at the University of

224 Adelaide and temperature was adjusted to simulate the conditions in the upper Spencer

225 Gulf based on temperature estimates recorded from Ward Spit (approximately $10 \mathrm{~km}$

226 from Point Lowly) in 2006 (Saunders, unpublished data). Temperature was therefore

227 slowly increased during the experimental period (July-November) from $13.8^{\circ} \mathrm{C}$ to $18^{\circ} \mathrm{C}$

$228\left( \pm 1^{\circ} \mathrm{C}\right)$. One standard fluorescent tube was used to illuminate the room and was adjusted

229 for brightness. Light was regulated on a $12 \mathrm{~h}$ light: $12 \mathrm{~h}$ dark photoperiod. The room

230 was monitored daily to ensure temperature and lights were functioning correctly.

\subsubsection{Seawater and brine collection}

Seawater was collected from the South Australian Research and Development Institute (SARDI), Aquatic Sciences Centre, West Beach, South Australia. The seawater originated from $1 \mathrm{~km}$ off shore at a depth of $10 \mathrm{~m}$ off the metropolitan coast of Adelaide

236 in Gulf St Vincent. The water was passed through a settlement tank and primary sand

237 filter before storage at the facility. The water was collected from SARDI on a weekly

238 basis and stored at constant temperature $\left(\sim 18^{\circ} \mathrm{C}\right)$ in a $2000 \mathrm{~L}$ tank in the aquarium room 239 at the University of Adelaide. 
242 desalination plant, Kangaroo Island, South Australia. The plant has been operating on a

243 small scale since 1999 producing 100 ML per year of freshwater. The plant uses

244 Reverse Osmosis (RO) technology to separate the salts from the seawater. Due to the

245 small volume of water which is desalinated, no chemicals are used, minimising the

246 impact of this brine on the marine environment. The starting salinity of the brine when

247 collected was $52 \%$, but this increased to $55 \%$ over the course of the experiment due to

248 evaporation. Brine was transported to the laboratory in a 1,000 L tank and once at the

249 laboratory, was stored in the aquarium room in a 1,000 L tank at constant temperature.

\subsubsection{Experimental design}

Eggs were carefully suspended onto 100 x $50 \mathrm{~mm}$ pieces of polystyrene floats

253

254

255

256

257

258

259

260

261

262

263

264

265

266

267

268

269

270

271

272

273

274

\subsubsection{Tank water quality}

Within the controlled temperature room a flow through system with a biological filter was not feasible. Water changes within treatments were therefore done manually. $\mathrm{pH}$ was maintained at 7.8-8.2. To maintain water quality for the requirements of cuttlefish $\left(\mathrm{NH}_{4}<0.5 \mathrm{mg} / \mathrm{L}, \mathrm{NO}_{2}<0.2 \mathrm{mg} / \mathrm{L}\right.$ and $\left.\mathrm{NO}_{3}<50 \mathrm{mg} / \mathrm{L}\right)($ Hanley et al., 1998; Minton, 2004) the levels of these three parameters were tested using an Aquarium Pharmaceuticals (API) liquid test kit. Nutrient tests were conducted mostly during the two consecutive days after a water change. However during the initial two weeks of the experiment nutrient analyses were conducted prior to a water change. Water changes (50-75 \%) were conducted every 3-5 days to maintain water quality and levels of trace elements which are needed for cephalopod development (Hanley et al., 1998). Water was changed within specific treatments when significant levels of nutrients within these 
275

276

277

278

279

280

281

282

283

284

285

286

287

288

289

290

291

292

293

294

295

296

297

298

299

300

301

302

303

304

305

306

307

tanks were detected. Water changes involved floating eggs out of tanks to avoid disturbance during the water change, removing built up detritus and refilling tanks with treatment water which was a mixture of seawater and desalination brine of the required salinity.

Concentrations of trace elements within experimental tanks were sampled on two occasions during the experimental period (August and September). Samples for water chemistry were analysed in a similar manner to the field samples.

\subsubsection{Length and weight of hatchlings}

Eggs were monitored daily until time of hatching. Date of hatching was recorded for each individual and minimum length of time to hatching determined based on eggs being laid on the day of collection. Percent survival was determined based on the number of individuals per tank per treatment which survived to hatching. Hatchlings were removed immediately from tanks once hatched and placed into an ice slurry. Length was measured using Mitutoyo digital blade type callipers ( $\pm 0.05 \mathrm{~mm})$ and wet weight, using an electronic balance ( $\pm 0.01 \mathrm{~g})$.

\subsubsection{Field samples}

Ten hatchlings were collected from Stony Point just prior to hatching in October to determine condition of wild cuttlefish. Length and weight measurements of hatchlings were determined in the laboratory using electronic callipers and an electronic balance.

\subsection{Statistical analyses}

Field data (number of clutches, nutrients, and trace elements) were analysed using two-factor (site, time) ANOVAs. All factors were treated as random. Homogeneity of variances was tested using Cochran's C test. If significant, data were transformed using $\operatorname{Ln}(\mathrm{X}+1)$, but if this transformation did not lead to homogeneity of variances, data analyses were made on non-transformed data. Where significant differences in ANOVAs were found Student-Newman Keuls (SNK) post-hoc tests were used to determine which sites or times differed. 

using a two-factor ANOVA (treatment and tanks nested within treatment), however no significant variation among tanks was found therefore data were pooled and analysed by treatment. The relationship between survival of eggs and salinity was determined using a logistic regression where the log likelihood was minimised.

\section{Results}

315

\subsection{Abundance of clutches}

317

318

319

The number of clutches of eggs showed a significant difference among sites, but similar patterns were seen for both years (Fig. $2 ; F_{8,8}=12.9, P<0.001$ ). Several sites had no eggs (e.g. sites 7 and 9 in year 1 and sites 2, 6, 7, 8 and 9 in year 2). Sites 1, 3 and 4 had significantly greater numbers of clutches than all other sites. Where clutches

3.2 Field water quality and chemistry compared to July (Fig. 3a; Table 2). Orthophosphate (OP) and ammonia $\left(\mathrm{NH}_{3 / 4}{ }^{+}\right)$ showed an interaction between sites and time of sampling because for one time (July) there were no significant differences among sites whereas for August, differences among sites were found (Fig. 3b and c; Table 2). In August, site 6 and site 8 had significantly higher concentrations of OP and $\mathrm{NH}_{3 / 4}{ }^{+}$than the other sites, and than July values (Fig. 3; Table 2).

Zinc showed no significant difference among sites or times (Fig. 4g, Table 3). Concentrations of Ba and Fe were significantly greater during August than July, but did not vary among sites (Fig. 4a and d, Table 3). For the remaining four elements (Sr, Ca, $\mathrm{K}, \mathrm{Mg}$ ) a significant interaction between site and time was found largely because for July there were no significant differences among sites, whereas for August some sites differed (Fig. 4b, c, e and f). Concentrations of Sr, Ca, K and Mg at site 8 were significantly lower than all other sites with the exception of site 6 ( $\mathrm{Sr}, \mathrm{Ca}, \mathrm{K}, \mathrm{Mg}$ ) and 9

341 (Ca, K, Mg) (Fig. 4). 


\subsection{Field environmental parameters}

344

345

346

347

348

349

350

351

352

353

354

355

356

357

358

359

360

361

362

363

364

365

366

367

368

369

370

371

372

373

374

Measurements of the environmental parameters showed little variation by depth therefore mean \pm standard error for each site and time was calculated throughout the entire water column (Table 4). Water temperature did not vary among sites on each of the sampling occasions (July $<0.35^{\circ} \mathrm{C}$ mean difference among sites; August maximum difference $\left.1.07^{\circ} \mathrm{C}\right)$. Mean water temperature in August $\left(14.62 \pm 0.05^{\circ} \mathrm{C}\right)$ was $2.21^{\circ} \mathrm{C}$ greater than in July $\left(12.40 \pm 0.04^{\circ} \mathrm{C}\right)$. Salinity was also constant across all sites during both months. The mean salinity across all sites within the breeding ground was $38.77 \%$ ( \pm 0.05 ). The highest average salinity was recorded at site $9,39.42 \%$ during July (Table 4). Dissolved oxygen varied among sites (Table 4). Sites 4 and 9 had the highest levels of DO on average than any of the other sites. The minimum mean value of dissolved oxygen for any site in either of the two sampling periods was $6.06 \mathrm{mg} / \mathrm{L}$ (site 1 in August) suggesting that the water was well oxygenated. $\mathrm{pH}$ readings were constant throughout each month, but were marginally higher across all sites during August compared to July. The average $\mathrm{pH}$ in July was $8.37( \pm 0.02)$ compared to August which was 8.48 ( \pm 0.02$)$. The maximum depth of the sites varied from $\sim 2 \mathrm{~m}$ to just under $6 \mathrm{~m}$, and showed some variation between the two sampling times, which was largely due to how close to the shore the boat could get during the rough weather in August.

\subsection{Embryo growth experiment}

\subsubsection{Water quality and chemistry}

The water quality, salinity and temperature in the experimental tanks are summarised in Table 5. The level of $\mathrm{NH}_{4}$ and $\mathrm{NO}_{3}$ were within optimum concentrations $\left(\mathrm{NH}_{4}<0.5 \mathrm{mg} / \mathrm{L}\right.$ and $\left.\mathrm{NO}_{3}<50 \mathrm{mg} / \mathrm{L}\right)$ throughout the experimental period within all treatments. Levels of $\mathrm{NO}_{2}$ were elevated $(>0.2 \mathrm{mg} / \mathrm{L})$ in higher salinity treatment tanks. Salinity did not fluctuate greatly within treatments, however within the brine treatment there was an average gradual salinity increase of $3.42 \%$, over the experimental period. $\mathrm{pH}$ levels were maintained at 7.8 within all treatments, however $\mathrm{pH}$ was elevated in the brine treatment (range 7.8-8.2 for 55 treatment). Water temperature increased within all treatments by $4.50^{\circ} \mathrm{C}\left( \pm 0.50^{\circ} \mathrm{C}\right)$ and closely matched the measured temperatures 
375 recorded in upper Spencer Gulf in 2006. Thus, experimental treatments were exposed

376 to a similar temperature regime to nature.

377

378

An increase in elemental concentration with an increase in salinity occurred for

379

Ba, Ca, K, Sr and Mg (Fig. 5 a, b, c, e and f), but this increase was only significant for 4

380

of the 5 elements (not significant for $\mathrm{Ba}$ ). There was no significant difference between

381

treatments for Fe and Zn (Fig. 5 d and g).

382

383

\subsubsection{Hatching success}

384

Hatching success was similar between the $39 \%$ (control, no brine) and $40 \%$

385

treatments, but then decreased for $45 \%$. In the $50 \%$ and $55 \%$ treatments there was

386

total mortality of eggs $\left(F_{4,5}=340.18, P<0.0001\right.$; Fig. 6a). A logistic regression was

387

fitted to the data [percent survival $=\exp \left(\mathrm{B}_{0}+\mathrm{B}_{1} \times\right.$ salinity $) /\left(1+\exp \left(\mathrm{B}_{0}+\mathrm{B}_{1} \times\right.\right.$ salinity $)$

where $\mathrm{B}_{0}=30.256 \pm 5.979$, and $\left.\mathrm{B}_{1}=-0.666 \pm 0.132\right]$. Thus, there was $\sim 7 \%$ decrease

389

in survival for every $1 \%$ increase in salinity. It was also noted that one embryo in the

390

$45 \%$ was malformed. For those treatments where individuals survived through to

391

hatching, the minimum average time to hatching was 99 days. There was no difference

392

between the length of time to hatching among the three treatments $\left(F_{2,59}=0.3323, P=\right.$

393 0.738; Fig. 6b).

394

395

\subsubsection{Length and weight of hatchlings}

396

397

There was a significant difference between the mantle lengths and weights of the hatchlings (Mantle length: $F_{3,68}=9.514, P<0.001$; Fig 7a; Weight: $F_{3,68}=9.501, P<$ 0.001; Fig 7b). Field-collected specimens were significantly larger and heavier than any of the treatment individuals. Of the laboratory treatments, individuals from $45 \%$ 
402

403

404

405

406

407

408

409

410

411

412

413

414

415

416

417

418

419

420

421

422

423

424

425

426

427

428

429

430

431

432

433

434

435

\section{Discussion}

The primary egg-laying area for S. apama lies between Point Lowly and Black Point in the upper Spencer Gulf (Hall and Hanlon, 2002). Within this region certain areas had a greater number of clutches. Differences in cephalopod egg abundance between sites within a particular region are common. A previous study found that the number of $S$. apama eggs varied among areas within a single site of the breeding aggregation, although the difference was not statistically significant (Hall and Fowler, 2003). Spatial variability of egg abundance on a small spatial scale (within a $1 \mathrm{~km}$ ) has also been found for squid species (Moltschaniwskyj and Pecl, 2003). The differences between sites may be attributed to the fine-scale variability of substrate within the breeding aggregation. The study area in the upper Spencer Gulf is made up of a hard substrate which constitutes a conspicuous and finite area. The area with the highest number of clutches maintained a clear slaty bed rock which was the most suitable for egg-laying (Gostin et al., 1984; Hall and Fowler, 2003). Knowledge of primary egglaying sites can contribute to a more informed decision as to where an intake and discharge pipe for seawater desalination should be placed.

The benthic eggs are exposed to water surrounding them during the austral winter. Values for nutrients and environmental variables near Point Lowly were generally considered moderate to good according to the ANZECC guidelines (ANZECC, 2000). Several sites (6 and 9) did exceed trigger values for nutrients (ammonia and orthophosphate) at one sampling time. Caution will therefore be required to ensure that the brine discharge does not lead to elevated nutrient concentrations. Although it is difficult to find guidelines for many of the trace elements for Australian waters, trace elements are likely to be increased in brine, which if not dispersed may lead to elevated levels in the vicinity of giant Australian cuttlefish eggs. Salinity is already elevated in upper Spencer Gulf due to the lack of freshwater input and inverse estuary nature of the gulf (Nunes Vas et al. 1990). Salinity was lower on average during this sampling period (38.78\%) compared to mean salinities of $40 \%$ recorded in March, 1984, 41 \%o in August, 1975 and 42.6 \%o in July, 1976 (Johnson, 1981; Nunes and Lennon, 1986). The brine is expected to have double the concentration of salts (70-80\%), higher temperature and turbidity than ambient seawater, and lower dissolved oxygen levels. In addition, concentrations of trace 
436 elements may be increased by 50\% (Vanhems 1992, cited in Einav et al. 2002).

437 Continual discharge of brine from a desalination plant could potentially cause changes

438 in nutrients, trace elements and environmental parameters which may negatively impact

439 the environment.

440

Increased concentrations of desalination brine had an inhibitory effect on hatching success and the growth and development of S. apama embryos. Embryos from treatments whose salinities were closest to those found in nature had the most successful hatch rate. The salinities in the field during the peak egg developmental period range from 38 \% to 42 \% (Johnson, 1981). Significantly fewer embryos survived to full term in salinities of $45 \%$ and complete mortality occurred in treatments greater than this concentration. Salinity ranges for embryonic development in cephalopods are species specific, and previous research has shown that between $34 \%$ and 42 \% is optimal (D'Aniello et al., 1989; Paulij et al., 1990; Cinti et al., 2004; Sen, 2004). The current study has indicated that salinity which increases above $40 \%$ will lead to a decrease in survivorship of S. apama embryos and that with every $1 \%$ increase in salinity above $40 \%$ survival of embryos will decrease by $~ 7 \%$.

Although physiological uptake of oxygen and nutrients by cuttlefish embryos occurs through the egg capsule by diffusion and the egg acts as a protective structure (Cronin and Seymour, 2000), osmotic stress has been inferred as a possible cause for malformations in developing cephalopod embryos (Paulij et al., 1990). A malformation of a single embryo in the $45 \%$ o treatment was observed. The individual survived almost to the hatching phase, however by the completion of the experiment, had died and its morphology had become unidentifiable. In the absence of any circulatory mechanism to aid oxygen transport to the tissue, oxygen must pass by diffusion from the external environment through the egg capsule to the embryo (Cronin and Seymour, 2000). Increased salinity causes a diffusion limitation to the respiration of the embryos. The solubility of gases, such as oxygen, is decreased in hypersaline water because the salts reduce the solubility of gases (Sherwood et al., 1991; Porter et al., 1999). Osmotic stress probably demanded a lot of energy which could not be used for development (Paulij et al., 1990). The increased mortality with the increased salinity of desalination brine may have also encouraged the inhibitory effects of microscopic bacteria or pathogenic fungi.

469 The fine layer of algal growth which covered the outer layer of the eggs was increased 
470

471

472

473

474

475

476

477

478

479

480

481

482

483

484

485

486

487

488

489

490

491

492

493

494

495

496

497

498

499

500

501

502

503

within treatments containing more brine. Pathogenic infections resulted in mortality of oysters when they were exposed to desalination brine (Mandelli and McIlhenny, 1971).

The inhibition of normal metabolic activity also caused the embryos in higher salinities to be smaller than hatchlings in the ambient salinity treatment. Previous research has shown that abiotic factors such as salinity have the potential to decrease the nutritional condition of developing larvae, as indicated by their length and weight (Folkvord et al., 1996). The decrease in mantle size as an effect of salinity has been noted previously and described as a malformation (Paulij et al. 1990). Also, correlations with size of hatchlings and hatching success have been determined for cephalopod embryos grown in low salinities (Palmegiano and Dapote, 1983; Fagundez and Robaina, 1992; Cinti et al., 2004; Sen, 2004; Sen, 2005; Villanueva et al., 2007); however this is the first study which indicates a decrease in weight and mantle length in salinities greater than $42 \%$. The yolk reserves of individual eggs are the only energy source for development of the embryo; the smaller the hatchling, the greater the physical constraints imposed on the functional morphology of organs responsible for swimming and food capture, therefore once hatched survivability may also be decreased (Boyle and Boletzky, 1996).

Development time of cuttlefish embryos was what was expected of eggs laid in July. Embryonic development varies between 3 and 5 months depending when the eggs were laid as development of S. apama eggs is mostly influenced by water temperature (Hall and Fowler, 2003). The mean developmental period of 99 days also supports the findings for S. apama eggs grown in situ in another study where the developmental time was 100 days in a controlled temperature environment ranging from $16^{\circ} \mathrm{C}$ to $18^{\circ} \mathrm{C}$ (Hall and Fowler, 2003).

Desalination brine concentrates not only salts, but metals and trace elements during the process of extracting fresh water (Talavera and Quesada Ruiz, 2001).

Although S. apama eggs may already be exposed to heavy metals and trace element concentrations, due to the breeding aggregations proximity to major industry, increased concentrations of trace elements may have been a cause of mortality in the experiment as concentrations of some trace elements were far greater than those found within waters near the breeding aggregation. Metals retard embryos from hatching at concentrations equal to or lower than those causing mortality and the effects of metals on embryos are often increased as a function of exposure duration (Macdonald et al., 1988). Loligo vulgaris embryos reared in different concentrations of trace elements only 
504 developed normally in a concentration range of 360.7-601.2 mg/L of calcium, 351.9-

$505 \quad 586.5 \mathrm{mg} / \mathrm{L}$ for magnesium and 1166.6-1652.7 mg/L for potassium. Above or below

506 these ranges mortality occurred and surviving hatchlings experienced reduced mobility

507 (D'Aniello et al., 1989). In the current study, the calcium levels were within this

508 survivability range, however magnesium concentrations were above this threshold for

509 the $50 \%$ and $55 \%$ tanks. The concentrations of potassium were also above natural

510 levels in the experimental tanks of 45 \%, 50 \%o, and 55 \%. Hatchlings were less active

511 within the $45 \%$ o treatment tanks which may be attributed to the high levels of

512 magnesium in the water (D'Aniello et al., 1989). Once hatched the cuttlefish in this

513 treatment were sluggish and very few inked to escape capture (Dupavillon, personal

514 observation). By comparison, cuttlefish in the control (39 \%) and $40 \%$ treatments

515 swam actively and inked multiple times in defence against capture.

516 With the potential increased concentrations of trace elements and metals

517 reaching the ocean through the discharge of desalination brine, it is vital to determine its

518 effects upon all life stages of S. apama. Research on the bioaccumulation of zinc into

519 early life stages of cuttlefish indicates that metals are taken up by cuttlefish eggs

520 (Bustamante et al., 2002). They appear to remain concentrated within the capsule

521 membrane of the egg, which thus acts as an efficient shield protecting the embryo

522 against exposure. Once hatched however the juvenile hatchlings assimilate heavy metals

523 into their tissues quite readily (Bustamante et al., 2002). Immediately after hatching,

524 rapid increases of $\mathrm{Cu}$, Fe and $\mathrm{Zn}$ concentrations in cuttlefish tissues have been found.

525 This suggests that hatchlings are highly dependent on essential metals to fulfil their

526 metabolic demands. It therefore follows that salts and metals are rapidly taken up once

527 the hatchling is in contact with seawater (Miramand et al., 2006). Exposure to effluents

528 of desalination plants may lead to accumulation of trace elements (Hanna and Muir,

529 1990).

530 A large-scale desalination plant which discharges concentrated brine effluent

531 into the vicinity of S. apama's breeding aggregation could possibly be detrimental to the

532 future survival of the population. These findings are important to the design and

533 development of a desalination plant in this area and can possibly be used to infer

534 impacts upon other benthic organisms. Pelagic organisms, such as teleosts are able to

535 move away from intolerable conditions such as discharged desalination brine. Benthic

536 organisms, for which certain life stages are mobility impaired, must have pre-

537 adaptations to withstand such environmental fluctuations. Risks of increased salinity 
538 and increased concentrations of nutrients and trace metals on the eggs of cuttlefish are

539 primarily associated with the properties of hypersaline water and the ecology of the

540 eggs themselves. S. apama eggs are laid in shallow water, and remain in the benthic

541 environment during their long developmental period; movement away from adverse

542 conditions is therefore not feasible. Hypersaline water is denser than normal seawater

543 and therefore sinks and accumulates on the bottom. In a laboratory setting the embryos

544 of S. apama do not survive the effects of desalination brine. A reduced number of

545 hatchlings would be expected at a very small increase in salinity, and therefore it is

546 essential that any outlet pipe is in a region away from the S. apama breeding

547 aggregation and that the discharged flow returns to background salinity levels relatively

548 quickly.

549 The potential placement of the feed water and discharge pipe for the desalination

550 plant needs to be carefully considered. Feed water, containing elevated concentrations

551 of salt, such as those found in the upper Spencer Gulf, and high levels of nutrients and

552 heavy metals should be avoided. These constituents are doubled in the discharge brine

553 and at such high concentrations are detrimental to a wide variety of marine organisms

554 (Epifanio and Srna, 1975; Talavera and Quesada Ruiz, 2001). The region of high egg

555 abundance should be avoided also as a feedwater and discharge point, as not only will

556 the brine have an effect on the developing embryos, but the infrastructure of the pipes

557 may disturb this unique egg-laying habitat. Impingement and entrapment of the eggs

558 and adult cuttlefish in these areas may also be possible (Gleick et al., 2006). These areas

559 supply the population with the most offspring and therefore should be properly

560 protected and conserved.

561

562

\section{Conclusion}

563 This study has focused on the benthic egg stage of the giant Australian cuttlefish

564 in terms of the effects of brine. Brine typically has increased levels of turbidity,

565 temperature and salinity and decreased levels of dissolved oxygen. Turbidity in

566 particular may also affect the adult stages since their mating system relies on visual cues

567 (Hall and Hanlon, 2002). Therefore, future studies need to focus on examining the

568 potential impacts of desalination brine on adults as well. The strength of one generation

569 is highly dependant on the strength of the previous generation since cuttlefish only live

570 for 12 to 18 months (Hall and Fowler, 2003). Therefore, any detrimental affects from

571 discharge brine may be catastrophic for the population as a whole. The finding that the 
572 embryos of S. apama can not survive increased levels of salinity and certain trace

573 elements is useful for the planning of desalination and for gaining insights into the

574 physiology of the species itself. Locally, knowledge of the key egg-laying sites within

575 the breeding aggregation will enable more cautious decision making from companies

576 proposing to proceed with large-scale industry of any kind within the unique spawning

577 grounds. Water quality, water chemistry and environmental parameters which have been

578 established in the breeding aggregation also form a baseline data set.

579

\section{Acknowledgements}

581 We acknowledge the help of Nick Payne in the field, and Rob Lister for assisting with

582 looking after cuttlefish. Helpful comments on an earlier version of the manuscript were

583 provided by Ian Whittington. Research was approved by the University of Adelaide

584 Animal Ethics Committee.

585

586

References

587

588

589

ANZECC 2000. Australian and New Zealand guidelines for fresh and marine water quality. Australian and New Zealand Environment and Conservation Council and

590 Agriculture and Resource Management Council of Australia and New Zealand.

591 Canberra.

592

593

594

595

596

597

598

599

600

601

602

603

604

605

606

607

608

609

610

611

612

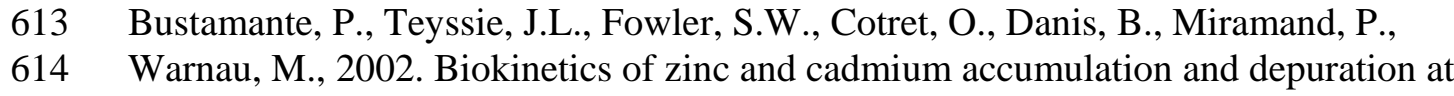

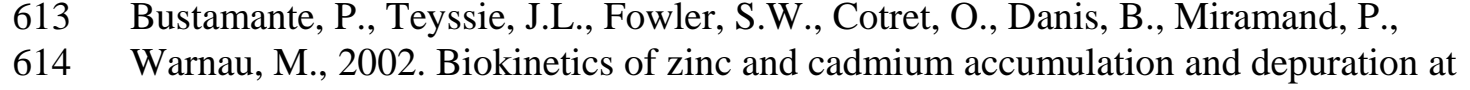

Aladin, N.V., 1991. Salinity tolerance and morphology of the osmoregulation organs in Cladocera with special reference to Cladocera from the Aral Sea. Hydrobiologia 225, 291-299.

Arnal, J.M., Sancho, M., Iborra, I., Gozalvez, J.M., Santafe, A., Lora, J., 2005.

Concentration of brines from RO desalination plants by natural evaporation.

Desalination 182, 435-439.

Barker, R., van Koppen, B., Shah, T., 2000. 'A global perspective on water scarcity and poverty: Achievements and challenges for water resources management.' International Water Management Institute (IWMI). Colombo, Sri Lanka.

Bayly, I.E., 1972. Salinity tolerance and osmotic behaviour of animals in athalassic saline and marine hypersaline waters. Annual Review of Ecology and Systematics 3, 233-268.

Boyle, P.R, Boletzky, S.V., 1996. Cephalopod populations: Definition and dynamics. Philosophical Transactions of the Royal Society of London. Biological Sciences 351, 985-1002. 
615 different stages in the life cycle of the cuttlefish Sepia officinalis. Marine Ecology

616 Progress Series 231, 167-177.

617

618 Cinti, A., Baron, P.J., Rivas, A.L., 2004. The effects of environmental factors on the

619 embryonic survival of the Patagonian squid Loligo gahi. Journal of Experimental

620

621

622

623

624

625

626

627

628

629

630

631

632

633

634

635

636

637

638

639

640 Marine Biology and Ecology 313, 225-240.

Cintron, G., 1970. Some consequences of brine pollution in the Bahia Fosforescente, Puerto Rico. Limnology and Oceanography 15, 246-249.

Cronin, E.R., Seymour, R.S., 2000. Respiration of the eggs of the giant cuttlefish Sepia apama. Marine Biology 136, 863-870.

D'Aniello, A., D’Onofrio, G., Pischetola, M., Denucei, J.M., 1989. Effect of pH, salinity and $\mathrm{Ca}^{+2}, \mathrm{Mg}^{+2}, \mathrm{~K}^{+}$and $\mathrm{SO}_{4}{ }^{+2}$ ions on hatching and viability of Loligo vulgaris embryo. Comparative Biochemistry and Physiology 94, 477-481.

Edgar, G.J., Barrett, N.S., Morton, A.J., 2004. Biases associated with the use of underwater visual census techniques to quantify the density and size-structure of fish populations. Journal of Experimental Marine Biology and Ecology 308, 269-290.

Einav, R., Harussi, K., Perry, D., 2002. The footprint of the desalination processes on the environment. Desalination 152, 141-154.

Epifanio, C.E., Srna, R.F., 1975. Toxicity of ammonia, nitrite ion, nitrate ion, and orthophosphate to Mercenaria mercenaria and Crassostrea virginica. Marine Biology

641 33, 241-246.

642

643

644

645

646

Fàgundez, S.B., Robaina, G., 1992. Effects of temperature, salinity, and photoperiod in the embryonic development of the squid Sepioteuthis sepioidea (Blainville, 1823). Memoria de la Sociedad de Ciencias Naturales La Salle 52, 93-103.

Fernández-Torquemada, Y., Sánchez-Lizaso, J.L., Gonza'lez-Correa, M., 2005. Preliminary results of the monitoring of the brine discharge produced by the SWRO desalination plant of Alicante (SE Spain). Desalination 182, 395-402.

Folkvord, A., Ystanes, L., Johannessen, A., Moksness, E., 1996. RNA: DNA ratios and growth of herring (Clupea harengus) larvae reared in mesocosms. Marine Biology 126, 591-602.

661

662

Giménez, L., Anger, K., 2001. Relationships among salinity, egg size, embryonic development, and larval biomass in the estuarine crab Chasmagnathus granulata Dana, 1851. Journal of Experimental Marine Biology and Ecology 260, 241-257.

Gleick, P., Cooly, H., Wolff, G., 2006. With a grain of salt: An update on saltwater desalination. In: 'The world's water 2006-2007.' The biennial report on freshwater resources.' (Ed. HC P. H. Gleick, D. Katz, E. Lee, J. Morrison, M. Palaniappan, A. Samulon and G. Wolff.) pp. 51-89. (Island Press: Washington, DC). 
664 Gostin, V.A., Hails, J.R., Belperio, A.P., 1984. The sedimentary framework of Northern 665 Spencer Gulf, South Australia. Marine Geology 61, 111-138.

666 Gray, in South Australian waters. Final report to FRDC (Project No. 98/151). SARDI Aquatic Sciences, Adelaide, 289pp.

Hall, K.C., Hanlon, R.T., 2002. Principal features of the mating system of a large spawning aggregation of the giant Australian cuttlefish Sepia apama (Mollusca: Cephalopoda). Marine Biology 140, 533-545.

Hanley, J.S., Shashar, N., Smolowitz, R., Bullis, R.A., Mebane, W.N., Gabr, H.R., Hanlon, R.T., 1998. Modified laboratory culture techniques for the European cuttlefish Sepia officinalis. Biological Bulletin 195, 223-225.

Hanna, R.G., Muir, G.L., 1990. Red sea corals as biomonitors of trace metal pollution. Environmental Monitoring and Assessment 14, 211-222.

Hashim, A., Hajjaj, M., 2005. Impact of desalination plants fluid effluents on the integrity of seawater, with the Arabian Gulf in perspective. Desalination 182, 373-393.

Jibril, B.E-Y., Ibrahim, A.A., 2001. Chemical conversions of salt concentrates from desalination plants. Desalination 139, 287-295.

Johnson, J. E., 1981. Hydrological data for Upper Spencer Gulf 1975-1978. Department of Fisheries, South Australia. No. 3.

Macdonald, J.M., Shields, J.D., Zimmer-Faust, R.K., 1988. Acute toxicities of eleven metals to early life-history stages of the yellow crab Cancer anthonyi. Marine Biology 98, 201-207.

Mandelli, E.F., McIlhenny, W.F., 1971. 'A study of the effect of desalination plant effluents on marine benthic organisms.' United States Department of the Interior, 803.

Minton, J.W., 2004. The pattern of growth in the early life cycle of individual Sepia pharaonis. Marine and Freshwater Research 55, 415-422.

Miramand, P., Bustamante, P., Bentley, D., Kouéta, N., 2006. Variation of heavy metal concentrations (Ag, Cd, Co, Cu, Fe, Pb, V, and Zn) during the life cycle of the common cuttlefish Sepia officinalis. Science of the Total Environment 361, 132-143.

Moltschaniwskyj, N.A., Pecl, G.T., 2003. Small-scale spatial and temporal patterns of egg production by the temperate loliginid squid Sepioteuthis australis. Marine Biology 142, 509-516.

Nunes, R.A., Lennon, G.W., 1986. Physical property distributions and seasonal trends in Spencer Gulf, South Australia - an inverse estuary. Australian Journal of Marine and Freshwater Research 37, 39-53. 
713 Nunes Vas, R.A., Lennon, G.W., Bowers, D.G., 1990. Physical behaviour of a large, 714 negative or inverse estuary. Continental Shelf Research 10, 277-304.

715

716

717

718

719

720

721

722

723

724

725

726

727

728

729

730

731

732

733

734

735

736

737

Palmegiano, G.B., Dapote, M.P., 1983. Combined effects of temperature and salinity on cuttlefish (Sepia officinalis L) hatching. Aquaculture 35, 259-264.

Paulij, W.P., Bogaards, R.H., Denuce, J.M., 1990. Influence of salinity on embryonic development and the distribution of Sepia officinalis in the Delta area South Western part of the Netherlands. Marine Biology 107, 17-24.

Porter, J.W., Lewis, S.K., Porter, K.G., 1999. The effect of multiple stressors on the Florida Keys coral reef ecosystem: A landscape hypothesis and a physiological test. Limnology and Oceanography 44, 941-949.

Raventos, N., Macpherson, E., Garcia-Rubies, A., 2006. Effect of brine discharge from a desalination plant on macrobenthic communities in the NW Mediterranean. Marine Environmental Research 62, 1-14.

Sen, H., 2004. A preliminary study on the effects of salinity on egg development of European squid (Loligo vulgaris Lamarck, 1798). Israeli Journal of Aquaculture Bamidgeh 56, 95-101.

Sen, H., 2005. Incubation of European squid (Loligo vulgaris Lamarck, 1798) eggs at different salinities. Aquaculture Research 36, 876-881.

Sherwood, J.E., Stagnitti, F., Kokkinn, M.J., Williams, W.D., 1991. Dissolved oxygen concentrations in hypersaline waters. Limnology and Oceanography. 36, 235-250.

Talavera, P., Quesada Ruiz, J., 2001. Identification of the mixing processes in brine discharges carried out in Barranco del Toro Beach, south of Gran Canaria (Canary Islands). Desalination 139, 277-286.

URS Australia., 2002. 'Summary report: Introduction to desalination technologies in Australia.' A report prepared for the Department of Agriculture, Fisheries and Forestry Australia (AFFA), Australian Capital Territory. http://www.environment.gov.au/water/publications/urban/pubs/desalinationsummary.pdf (accessed 1 October 2008).

Vega-Cendejas, M.E., Hernández de Santillana, M., 2004. Fish community structure and dynamics in a coastal hypersaline lagoon: Rio Lagartos, Yucatan, Mexico.

Estuarine Coastal and Shelf Science 60, 285-299.

Villanueva, R., Moltschaniwskyj, N.A., Bozzano A., 2007. Abiotic influences on embryo growth: statoliths as experimental tools in the squid early life history. Reviews in Fish Biology and Fisheries 17, 101-110.

York, R., Foster, M., 2005. 'Issues and environmental impacts associated with once through cooling at California's coastal power plants.' California Energy Commission, 761 Sacramento, CA. 
763 Young, G.C., Potter, I.C., 2002. Influence of exceptionally high salinities, marked 764 variations in freshwater discharge and opening of estuary mouth on the characteristics 765 of the ichthyofauna of a normally-closed estuary. Estuarine, Coastal and Shelf Science 766 55, 223-246.

767

768 
771 Locations of study sites between Black Point and Point Lowly, upper Spencer Gulf, South Australia,

772 showing latitude and longitude (decimal degrees). See Fig. $1 b$ for figure of sites.

773

774

775

\begin{tabular}{lll}
\hline Site & South & East \\
\hline $\mathbf{1}$ & 32.991 & 137.720 \\
$\mathbf{2}$ & 32.993 & 137.727 \\
$\mathbf{3}$ & 32.995 & 137.739 \\
$\mathbf{4}$ & 32.996 & 137.752 \\
$\mathbf{5}$ & 32.996 & 137.758 \\
$\mathbf{6}$ & 32.994 & 137.773 \\
$\mathbf{7}$ & 32.000 & 137.782 \\
$\mathbf{8}$ & 32.100 & 137.787 \\
$\mathbf{9}$ & 32.994 & 137.785 \\
\hline
\end{tabular}


Table 2

777 Two-factor ANOVA results for the concentrations of dissolved nutrients (oxidised nitrogen, ammonia and orthophosphate) in seawater samples

\begin{tabular}{ccccc}
\hline & \multicolumn{2}{c}{$\begin{array}{c}\text { Oxidised } \\
\text { Nitrogen } \\
\left(\mathrm{NO}_{\mathrm{x}}\right)\end{array}$} & $\begin{array}{c}\text { Ammonia } \\
\left(\mathrm{NH}_{3 / 4}{ }^{+}\right)\end{array}$ & $\begin{array}{c}\text { Orthophosphate } \\
\text { (OP) }\end{array}$ \\
\hline Source of variation & d.f. & $\mathrm{MS}$ & $\mathrm{MS}$ & $\mathrm{MS}$ \\
Site & 8 & 0.1264 & 0.0027 & 0.2660 \\
Time & 1 & $1.9134^{* * *}$ & 0.0043 & 0.0050 \\
Site $x$ time & 8 & 0.0443 & $0.0031^{* * *}$ & $0.0270 * * *$ \\
Residual & 36 & 0.0710 & 0.0004 & 0.0034 \\
\hline
\end{tabular}

781

782

Note: MS indicates mean squares; $\mathrm{NO}_{\mathrm{x}}$ data were $\ln (\mathrm{x})$ transformed; Cochran's $C$ test was nonsignificant for $\mathrm{NO}_{\mathrm{x}}$ and $\mathrm{NH}_{3 / 4}{ }^{+}$, but significant for $\mathrm{OP}(P<0.01)$; ${ }^{*} P<0.05,{ }^{* *} P<0.01,{ }^{* * *} P<0.001$. 
Table 3

Two-factor ANOVA results for the concentrations of trace elements in seawater samples within the breeding aggregation in the upper Spencer Gulf

\begin{tabular}{|c|c|c|c|c|c|c|c|c|}
\hline & & $\begin{array}{l}\text { Barium } \\
(\mathrm{Ba})\end{array}$ & $\begin{array}{l}\text { Calcium } \\
\text { (Ca) }\end{array}$ & $\begin{array}{l}\text { Iron } \\
(\mathrm{Fe})\end{array}$ & $\begin{array}{l}\text { Magnesium } \\
(\mathrm{Mg})\end{array}$ & $\begin{array}{c}\text { Potassium } \\
(\mathrm{K})\end{array}$ & $\begin{array}{l}\text { Strontium } \\
(\mathrm{Sr})\end{array}$ & $\begin{array}{l}\text { Zinc } \\
\text { (Zn) }\end{array}$ \\
\hline Source of variation & d.f. & MS & MS & MS & MS & MS & MS & MS \\
\hline Site & 8 & 0.566 & 1721.296 & 5.973 & 18637.963 & 4404.167 & 675046.296 & 49.866 \\
\hline Time & 1 & $2.579 *$ & 5400.000 & $107.245^{*}$ & 63379.630 & 16016.667 & 2322962.960 & 187.787 \\
\hline Site $\mathrm{x}$ time & 8 & 0.350 & $2233.333 *$ & 14.342 & $22746.296^{*}$ & $5462.500 *$ & $827546.296 *$ & 51.956 \\
\hline Residual & 36 & 0.170 & 907.407 & 12.832 & 9253.704 & 1970.370 & 304259.259 & 35.751 \\
\hline
\end{tabular}

Note: MS indicates mean squares; Cochran's $C$ - test $(P<0.05)$ was significant for all elements. ${ }^{*} P<0.05$; ${ }^{* *} P<0.01,{ }^{* * *} P<0.001$. 
Table. 4

Mean values ( \pm standard error, s.e.) of environmental parameters of seawater (temperature, salinity, dissolved oxygen, pH) and depth as measured in July and August 2007, within the breeding aggregation near Point Lowly, upper Spencer Gulf. Values for depth are the maximum depth at which measurements were recorded for each site. Note: unless otherwise indicated, s.e. $=0$ because in July and August the same values were recorded across all depths. Note: $(-)=$ No data recorded.

\begin{tabular}{|c|c|c|c|c|c|c|c|c|c|c|}
\hline \multirow[t]{2}{*}{ Site } & \multicolumn{2}{|c|}{ Temperature $\left(\mathrm{C}^{\circ}\right)$} & \multicolumn{2}{|c|}{$\begin{array}{c}\text { Salinity } \\
\left(\%{ }_{00}\right)\end{array}$} & \multicolumn{2}{|c|}{ Dissolved $\mathrm{O}_{2}(\mathrm{mg} / \mathrm{L})$} & \multicolumn{2}{|c|}{$\Rightarrow \mathrm{pH}$} & \multicolumn{2}{|c|}{$\begin{array}{l}\text { Depth } \\
\text { (m) }\end{array}$} \\
\hline & July & August & July & August & July & August & July & August & July & August \\
\hline 1 & $\begin{array}{l}12.49 \\
( \pm 0.01)\end{array}$ & 14.75 & $\begin{array}{l}38.80 \\
( \pm 0.01)\end{array}$ & 38.58 & $\begin{array}{l}7.11 \\
( \pm 0.13)\end{array}$ & $\begin{array}{c}6.06 \\
( \pm 0.12)\end{array}$ & 8.39 & 8.48 & 2.58 & 5.24 \\
\hline 2 & $\begin{array}{l}12.47 \\
( \pm 0.01)\end{array}$ & 14.84 & $\begin{array}{l}38.84 \\
( \pm 0.01)\end{array}$ & 38.59 & $\begin{array}{l}7.58 \\
( \pm 0.06)\end{array}$ & $\begin{array}{c}6.19 \\
( \pm 0.06)\end{array}$ & 8.43 & 8.48 & 3.81 & 3.01 \\
\hline 3 & $\begin{array}{l}12.32 \\
( \pm 0.01)\end{array}$ & - & $\begin{array}{l}38.81 \\
( \pm 0.01)\end{array}$ & - & $\begin{array}{l}7.86 \\
( \pm 0.16)\end{array}$ & - & 8.40 & - & 3.18 & - \\
\hline 4 & 12.45 & 14.73 & 38.67 & & $\begin{array}{l}9.50 \\
( \pm 0.09)\end{array}$ & $\begin{array}{c}8.52 \\
( \pm 0.11)\end{array}$ & 8.38 & 8.49 & 4.72 & 2.78 \\
\hline 5 & $\begin{array}{l}12.63 \\
( \pm 0.01)\end{array}$ & 14.48 & 38. & - & $\begin{array}{l}8.78 \\
( \pm 0.23)\end{array}$ & $\begin{array}{c}7.40 \\
( \pm 0.11)\end{array}$ & 8.39 & 8.47 & 2.54 & 2.24 \\
\hline 6 & 12.28 & 15.00 & $( \pm 0.01)$ & 38.58 & $\begin{array}{l}6.72 \\
( \pm 0.11)\end{array}$ & $\begin{array}{c}8.97 \\
( \pm 0.03)\end{array}$ & 8.37 & 8.55 & 1.96 & 3.79 \\
\hline 7 & 12.32 & & $\begin{array}{l}38.81 \\
( \pm 0.02)\end{array}$ & - & $\begin{array}{l}6.61 \\
( \pm 0.17)\end{array}$ & - & 8.37 & - & 2.42 & - \\
\hline 8 & 12.28 & & 38.94 & - & $\begin{array}{l}8.19 \\
( \pm 0.07)\end{array}$ & - & 8.36 & - & 5.69 & - \\
\hline 9 & 12.40 & 13.93 & 39.42 & 38.86 & $\begin{array}{l}9.45 \\
( \pm 0.09)\end{array}$ & $\begin{array}{c}9.41 \\
( \pm 0.04)\end{array}$ & $\begin{array}{l}8.21 \\
( \pm 0.01)\end{array}$ & 8.42 & 5.90 & 4.08 \\
\hline
\end{tabular}


Table 5

Salinity, temperature, $\mathrm{pH}$ and seawater quality (mean \pm s.e.) for experimental treatment tanks, including range of values (in brackets), mean \pm s.e., and sample size $(n)$.

\begin{tabular}{ccccccc}
\hline Treatment & $\begin{array}{c}\text { Salinity }(\% 00), \\
(\text { mean })\end{array}$ & $\begin{array}{c}\text { Temperature } \\
\left({ }^{\circ} \mathrm{C}\right)\end{array}$ & $\mathrm{pH}$ & $\mathrm{NH}_{4}\left(\mathrm{mgL}^{-1}\right)$ & $\mathrm{NO}_{2}\left(\mathrm{mgL}^{-1}\right)$ & $\mathrm{NO}_{3}\left(\mathrm{mgL}^{-1}\right)$ \\
\hline 39 & $39.60( \pm 0.03)$ & & $7.8 \pm 0$ & $0.06 \pm 0.03$ & $0.18 \pm 0.02$ & $2.17 \pm 0.59$ \\
& $(39.04-39.98)$ & $(13.34-18.11)$ & & $(0-0.50)$ & $(0-0.25)$ & $(0-10.00)$ \\
& $n=50$ & $n=50$ & $n=6$ & $n=26$ & $n=43$ & $n=23$ \\
40 & $40.44( \pm 0.03)$ & & $7.8 \pm 0$ & $0.05 \pm 0.02$ & $0.18 \pm 0.01$ & $2.70 \pm 0.48$ \\
& $(40.10-41.05)$ & $(13.29-18.03)$ & & $(0-0.35)$ & $(0.10-0.25)$ & $(0-5.00)$ \\
& $n=49$ & $n=49$ & $n=6$ & $n=24$ & $n=43$ & $n=25$ \\
45 & $45.28( \pm 0.02)$ & & $7.8 \pm 0$ & $0.07 \pm 0.02$ & $0.32 \pm 0.02$ & $5.93 \pm 0.54$ \\
& $(45.06-45.62)$ & $(13.24-18.07)$ & & $(0-0.35)$ & $(0.10-0.50)$ & $(0-10.00)$ \\
& $n=51$ & $n=51$ & $n=4$ & $n=24$ & $n=45$ & $n=27$ \\
50 & $50.20( \pm 0.04)$ & & $7.8 \pm 0$ & $0.03 \pm 0.02$ & $0.4 \pm 0.03$ & $8.64 \pm 1.19$ \\
& $(49.62-50.43)$ & $(13.09-18.51)$ & & $(0-0.35)$ & $(0.15-1.00)$ & $(0-20.00)$ \\
& $n=54$ & $n=54$ & $n=6$ & $n=24$ & $n=42$ & $n=22$ \\
55 & $54.55( \pm 0.15)$ & $(13.42-17.93)$ & $8.0 \pm 0.1$ & 0 & $0.49 \pm 0.04$ & $9.58 \pm 1.08$ \\
& $(52.79-56.21)$ & $n=48$ & $(7.8-8.2)$ & 0 & $(0.15-1.00)$ & $(0-20.00)$ \\
& $n=48$ & & $n=8$ & $n=26$ & $n=42$ & $n=24$ \\
\hline
\end{tabular}


Table 6

Single-factor ANOVA results for the concentrations of trace elements in samples taken from experimental treatments.

\begin{tabular}{|c|c|c|c|c|c|c|c|c|}
\hline & & $\begin{array}{c}\text { Barium } \\
(\mathrm{Ba})\end{array}$ & $\begin{array}{l}\text { Calcium } \\
\text { (Ca) }\end{array}$ & $\begin{array}{l}\text { Iron } \\
(\mathrm{Fe})\end{array}$ & $\begin{array}{l}\text { Magnesium } \\
(\mathrm{Mg})\end{array}$ & $\begin{array}{c}\text { Potassium } \\
(\mathrm{K})\end{array}$ & $\begin{array}{c}\text { Strontium } \\
(\mathrm{Sr})\end{array}$ & $\begin{array}{l}\text { Zinc } \\
(\mathrm{Zn})\end{array}$ \\
\hline Source of variation & d.f. & MS & MS & MS & MS & MS & MS & MS \\
\hline Treatment & 4 & $2.931 n s$ & $0.071 * * *$ & $1.582 n s$ & $0.073 * * *$ & $41220.000 * * *$ & $6376750.000 * * *$ & $25.450 n s$ \\
\hline Residual & 15 & 1.247 & 0.001 & 1.239 & 0.001 & 1051.667 & 201666.667 & 50.850 \\
\hline
\end{tabular}

Note: MS indicates mean squares; ${ }^{*} P<0.05$; ${ }^{* *} P<0.01$, *** $P<0.001, n s=$ Not significant. 


\section{Figure captions}

Fig.1. (a) Map of the South Australian Gulf system showing the shape and orientation of Spencer Gulf and (b) the location of the key breeding ground for the aggregation of the giant Australian cuttlefish in the northern Spencer Gulf. Sites 1-9 extend from Black Point through to Point Lowly. Figure 1a taken from Hall and Fowler (2003) and Figure 1b from Google Earth.

Fig. 2. Mean ( \pm s.e.) number of clutches of cuttlefish eggs at nine sites within the breeding aggregation during 2007 and 2008.

Fig. 3. Concentrations of (a) oxidised nitrogen $\left(\mathrm{NO}_{\mathrm{x}}\right)$, (b) orthophosphate (OP) and (c) ammonia $\left(\mathrm{NH}_{3 / 4}{ }^{+}\right)$in seawater samples from nine sites within the breeding aggregation during July and August 2007. Shown are mean values ( \pm s.e.)

Fig. 4. Trace element concentrations ( $\mathrm{Ba}, \mathrm{Ca}, \mathrm{K}, \mathrm{Fe}, \mathrm{Sr}, \mathrm{Mg}$ and $\mathrm{Zn}$ ) (a-g) in seawater from nine sites within the breeding aggregation during July and August 2007. Shown are mean values ( \pm s.e.). Note: units vary among graphs.

Fig. 5. Trace element concentrations (Ba, Ca, K, Fe, Sr, Mg, and Zn) (a-g) in experimental treatment tanks. Tanks 1 and 2 represent the replicate tanks within each treatment. Shown are mean values ( \pm s.e.). Note: units vary among graphs.

Fig. 6. Mean ( \pm s.e.) (a) percent survival (\%) and (b) number of days to hatching of cuttlefish embryos which were reared in different concentrations of desalination brine. Note: $39 \%$ treatment was a control and contained no brine.

Fig. 7. Mean ( \pm s.e.) (a) mantle length ( $\mathrm{mm}$ ) and (b) weight of cuttlefish collected from Stony Point (site 4) in November 2007 (field) and of hatchlings from experimental tanks (39\%, $40 \%$ and $45 \%$ ) at the time of hatching. 
(a)

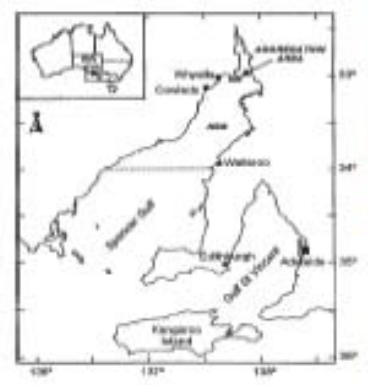

(b)

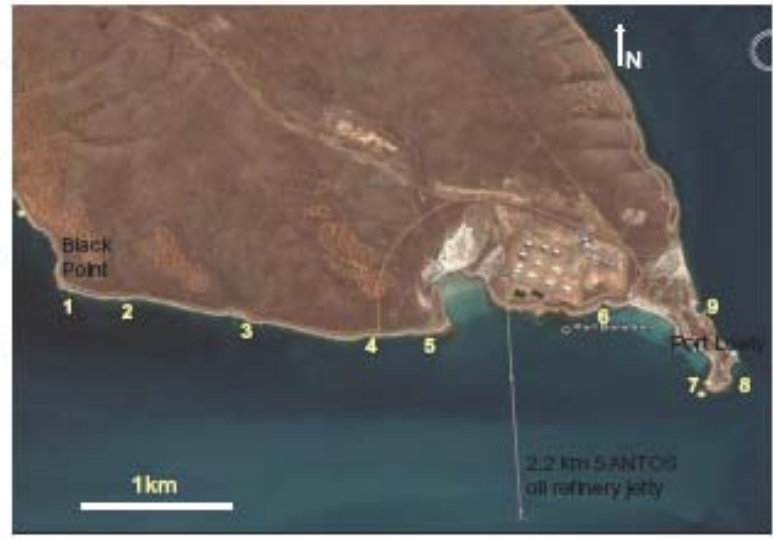

Fig 1 
Impacts of seawater desalination on the giant Australian cuttlefish

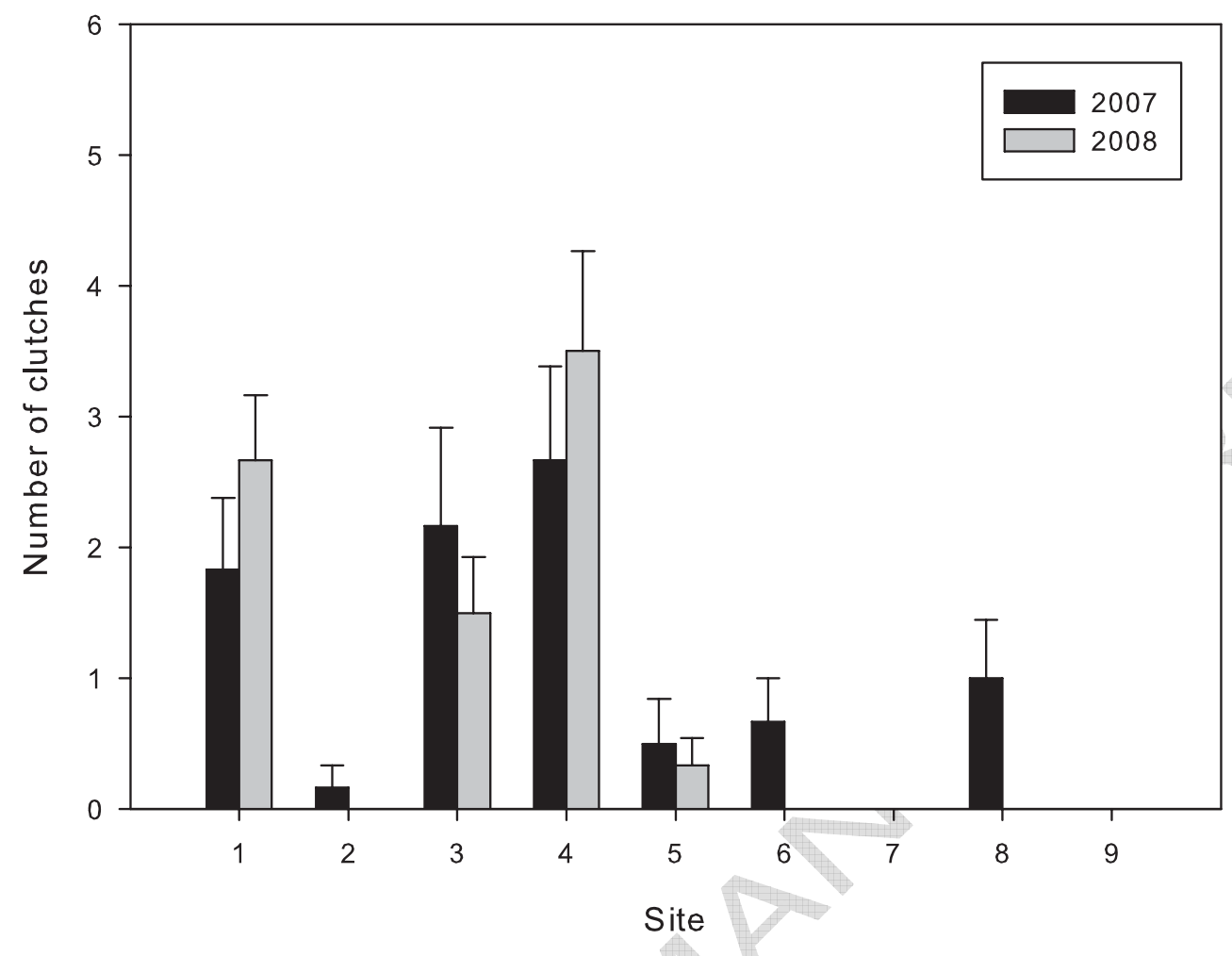

Fig 2 
Impacts of seawater desalination on the giant Australian cuttlefish
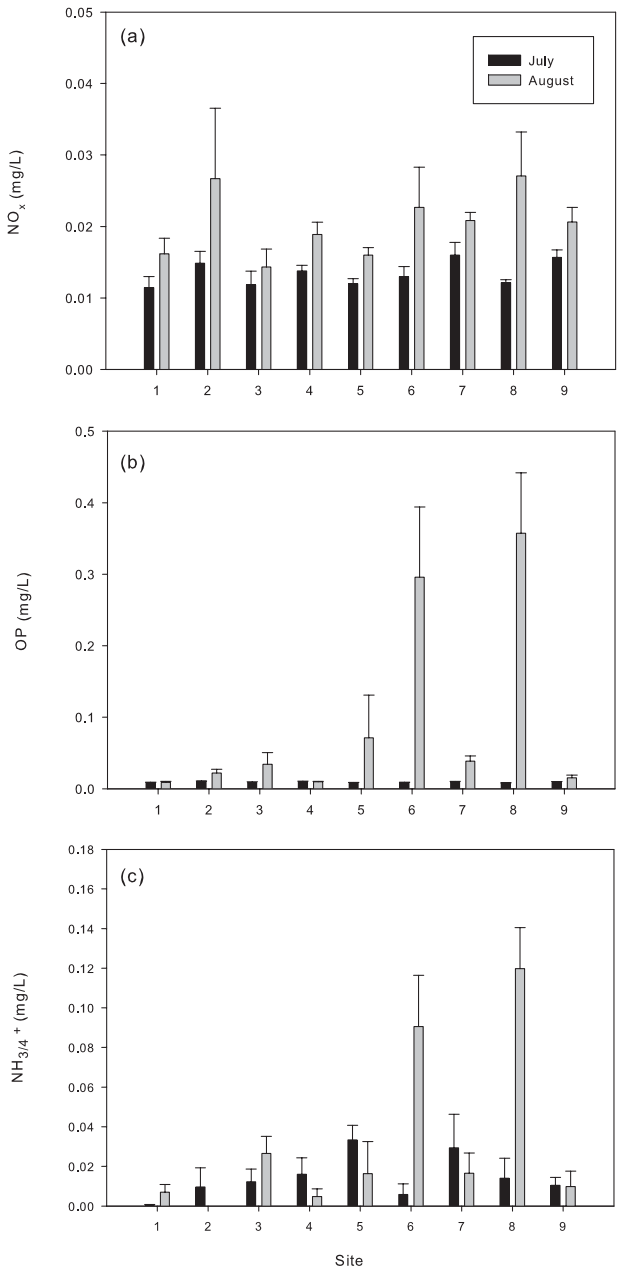

Fig 3 
Impacts of seawater desalination on the giant Australian cuttlefish
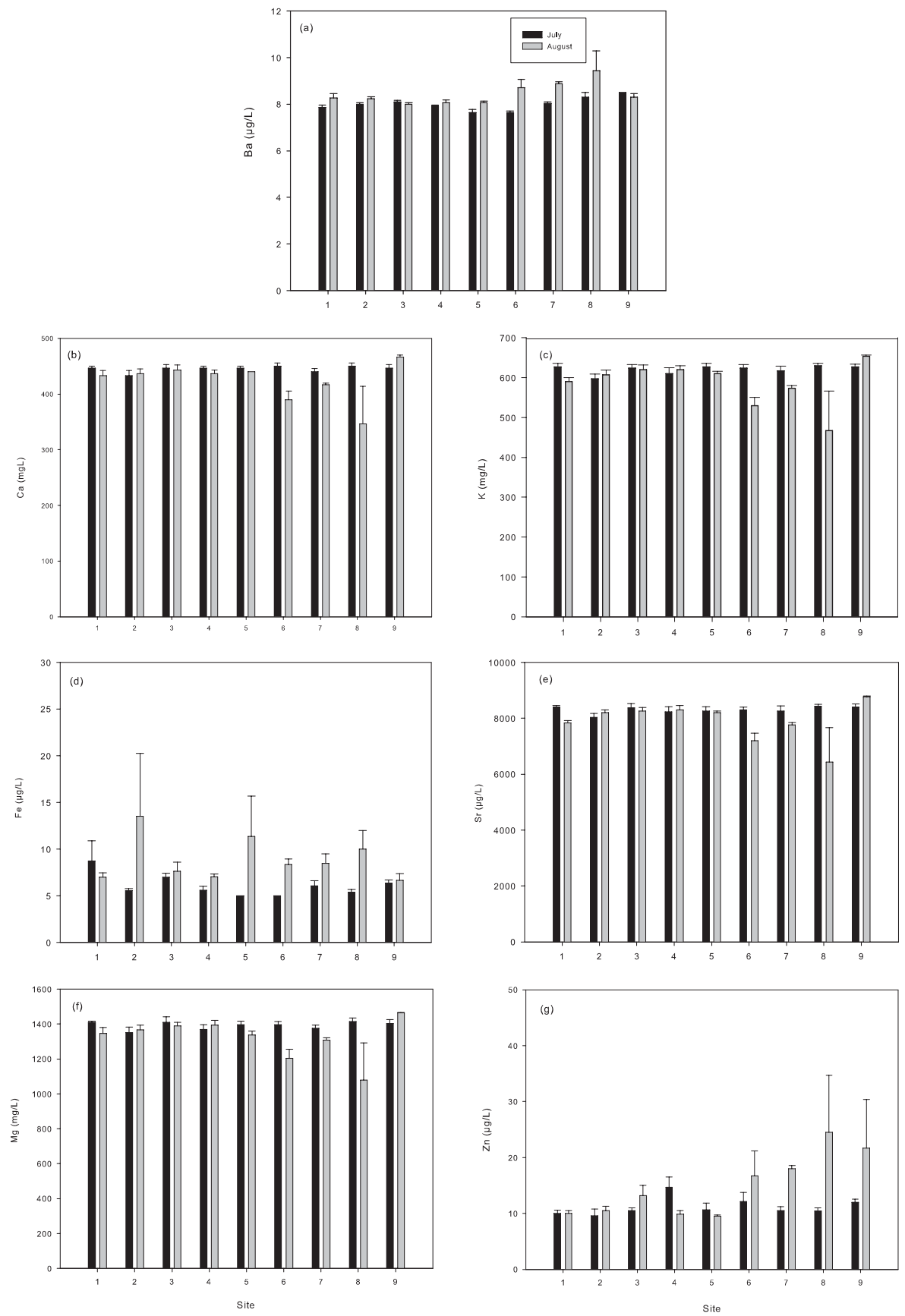

Fig 4 

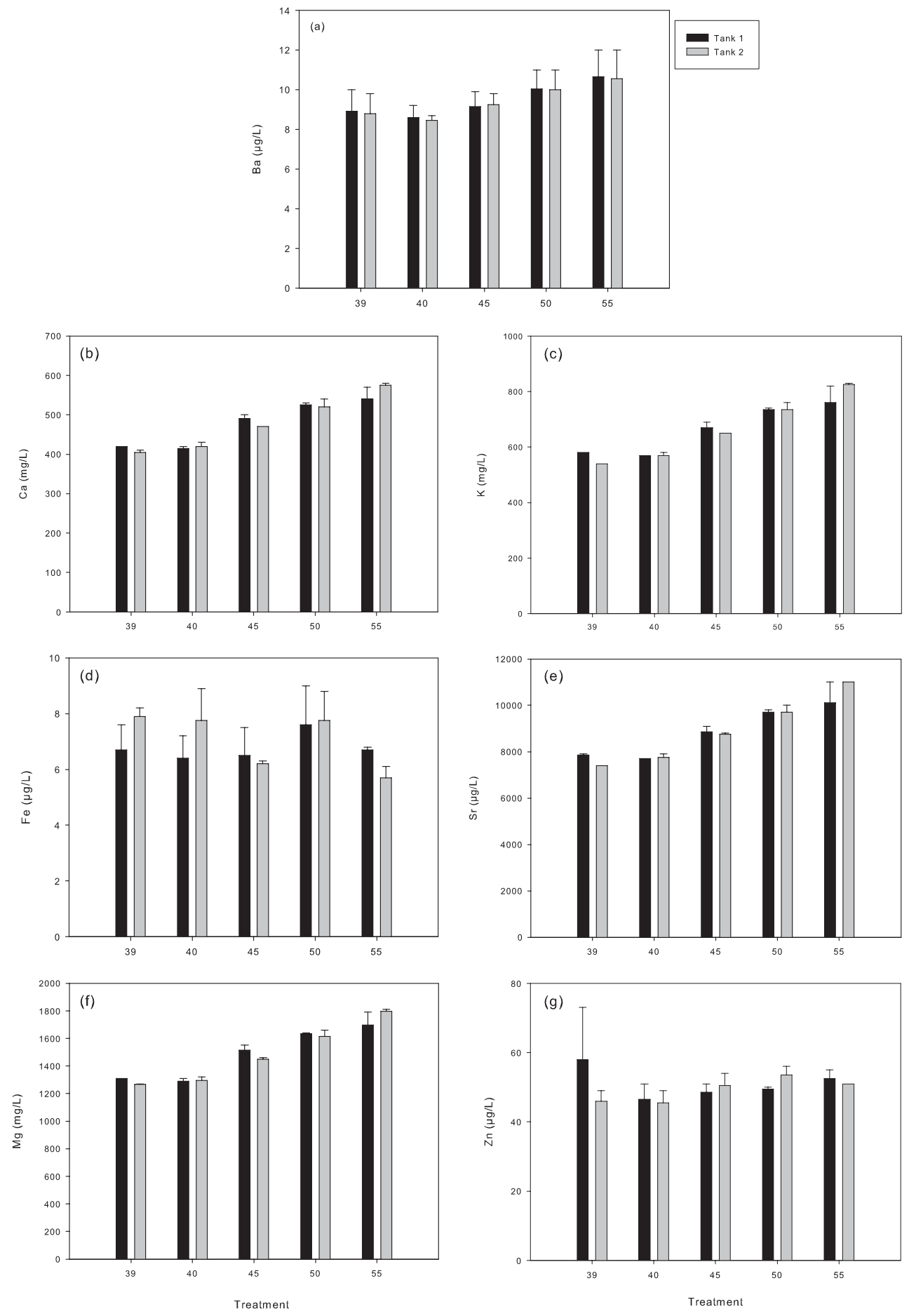

Fig 5 
Impacts of seawater desalination on the giant Australian cuttlefish

Fig 6
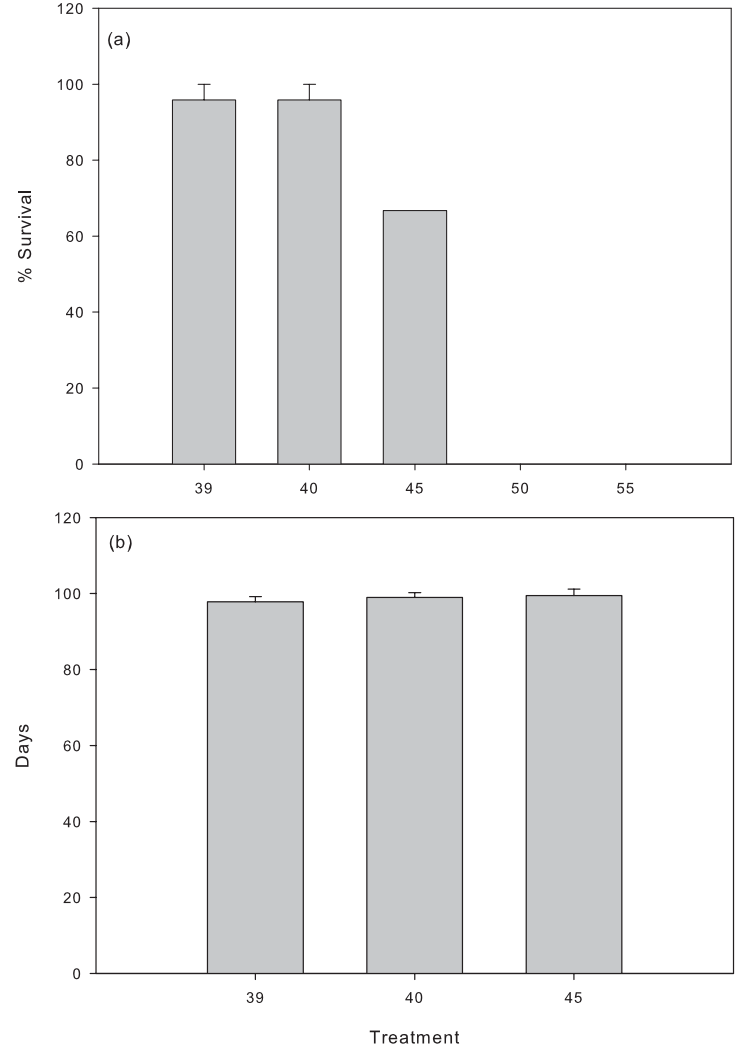
Impacts of seawater desalination on the giant Australian cuttlefish
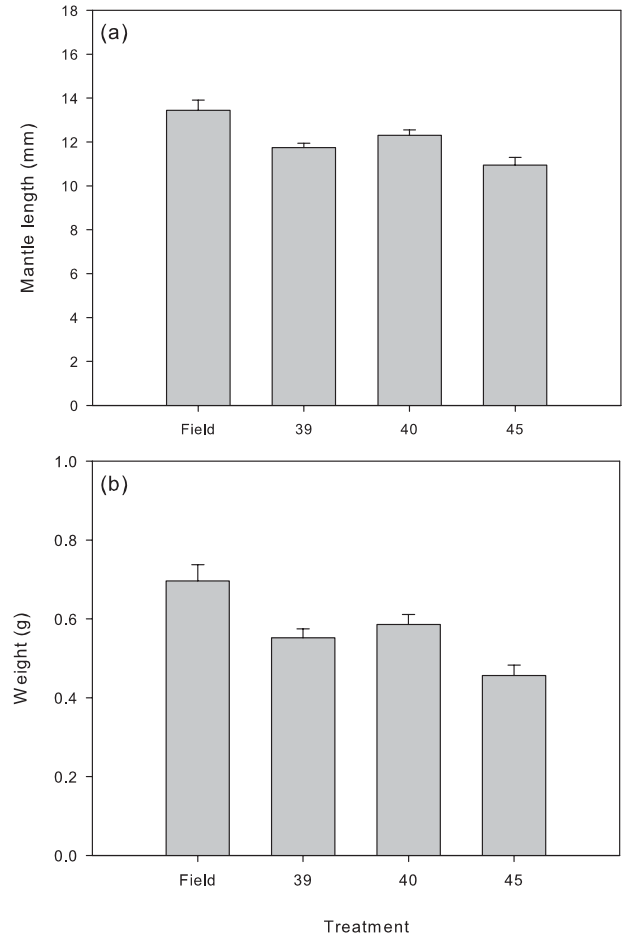

Fig 7 